\title{
PENERAPAN ROLE PLAYING BERBANTU MEDIA BONEKA JARI DALAM MENINGKATKAN AKTIVITAS DAN PERKEMBANGAN SOSIAL PERALIHAN ANAK DARI TK KE SD
}

\author{
Nurul Agustin a, , Ivo Yuliana ${ }^{\text {b, }, ~}$, Rizki Amelia Andayanic ${ }^{\mathrm{c}} 3$ \\ a,b.c STAI AL-AZHAR Menganti Gresik, Indonesia \\ 1urulagustinstaialazhar@gmail.com ${ }^{2}$ Ivoyuliana@gmail.com ${ }^{3}$ ameliarizki1207@gmail.com
}

\begin{tabular}{l}
\hline Informasi artikel \\
\hline Received : \\
Januari 20, 2022 \\
Revised : \\
Februari 13, 2022 \\
Publish :
\end{tabular}

Maret 03, 2022

Kata kunci:

Role Playing;

Boneka Jari;

Perkembangan Sosial.
Keywords:

Role Playing;

Finger Puppets;

Social Development

\begin{abstract}
ABSTRAK
Penelitian ini bertujuan untuk meningkatkan aktivitas dan perkembangan sosial anak peralihan dari taman kanak-kanak ke sekolah dasar melalui penerapan Metode Role Playing Berbantu Media Boneka Jari dengan menggunakan jenis Peneltian Tindakan Kelas (PTK). Penelitian ini ada empat tahap yang terdiri dari: perencanaan, pelaksanaan tindakan, observasi dan refleksi. Di setiap siklus melakukan 1 sampai 4 tahap tersebut dan setiap siklus akan melewati ke empat tahap tersebut. Dari hari penelitian aktivitas siswa dalam mengikuti kegiatan pembelajaran dengan penerapan metode role playing berbantu media boneka jari mencapai presentase $55 \%$ pada siklus I dan meningkat sebesar 37,5\% pada siklus II memperoleh presentase sebesar 92,5\%. Adapun hasil perkembangan sosial siswa ketika mengikuti kegiatan pembelajaran berlangsung memperoleh presentase sebesar 50\% meningkat 36,25 sebesar pada siklus II memperoleh presentase sebesar 86,25\%. Berdasarkan hasil tersebut dapat disimpulkan bahwa dengan penerapan metode role playing berbantu media boneka jari dapat meningkatkan aktivitas dan perkembangan sosial peralihan anak dari taman kanakkanak ke sekolah dasar.

\section{ABSTRACT}

This study aims to increase the activity and social development of children transitioning from kindergarten to elementary school through the application of the Finger Puppet Media Assisted Role Playing Method using the Class Action Research (CAR). This research has four stages consisting of: planning, action implementation, observation and reflection. In each cycle, 1 to 4 stages are carried out and each cycle will pass through these four stages. From the research day, the students' activities in participating in learning activities using the role playing method assisted by finger puppet media reached a percentage of $55 \%$ in the first cycle and increased by $37.5 \%$ in the second cycle, obtaining a percentage of $92.5 \%$. The results of the social development of students when participating in learning activities take place to obtain a percentage of 50\%, an increase of 36.25 in the second cycle, obtaining a percentage of $86.25 \%$. Based on these results, it can be concluded that by applying the role playing method assisted by finger puppet media, it can increase the activity and social development of children's transition from kindergarten to elementary school.
\end{abstract}

This work is licensed under a Creative Commons Attribution-ShareAlike 4.0 International License. Allows readers to read, download, copy, distribute, print, search, or link to the full texts of its articles and allow readers to use them for any other lawful purpose. 


\section{PENDAHULUAN}

Manusia mempunyai banyak sebutan salah satunya sebagai makhluk sosial yaitu makhluk yang tidak bisa hidup sendiri tanpa bantuan oranglain. Walaupun manusia termasuk golongan sebagai makhluk sosial, seorang anak masih butuh dorongan untuk dapat bersosialisasi dengan cara adanya pembiasaan sejak usia dini. Salah satu cara agar seorang anak dapat berinteraksi yaitu dengan aktif mengajak bermain. Dengan bermain seorang anak dapat menemukan hal yang baru dan dapat bersosialisasi dengan mengasah kemampuan dalam berkomunikasi.

Bermain merupakan bagian paling terpenting dalam perkembangan manusia. Dengan adanya permainan seorang anak dapat belajar mengenal dirinya sendirinya, masyarakat dan lingkungan. Makhluk sosial atau manusia aktif dalam berinteraksi dengan antar sesama manusia akan dapat mengembangkan kognitif, sosial, fisik dan emosinya. Dengan adanya hal tersebut seorang anak bukan hanya bermain melainkan belajar dan bermain, kegiatan yang paling menyenangkan adalah bermain dan sangat lumrah bagi anak-anak yang rentang usia 5-6 tahun dan bagi anak-anak yang sedang peralihan dari TK ke SD. Hal tersebut memang wajar sekali ketika menjumpai anakanak yang sedang duduk dibangku kelas 1 Sekolah Dasar.

Peralihan anak dari TK ke SD merupakan sesuatu yang baru dan mengagetkan bagi anak kelas 1, dimana dunia Pendidikan Taman Kanak-kanak aktivitasnya yang diawali dan diakhiri dengan bermain. Dengan adanya hal tersebut sekolah dasar harus memahami dan dapat memberikan banyak aktivitas bermain kepada anak kelas 1 sekolah Dasar ketika di dalam kelas. Dengan banyaknya aktivitas bermain hal tersebut dapat dikatakan sebagai salah satu cara untuk dapat membentuk kemampuan belajar anak, maka dalam proses kegiatan pembelajaran di kelas 1 Sekolah Dasar harus mampu mengembangkan kegiatan pembelajaran yang mengandung aktivitas anak dalam belajar dan bermain.

Dari hasil Observasi di SDN Jatikalang II Krian, aktivitas siswa kelas 1 dalam kegiatan pembelajaran sangatlah pasif dan interaksi antar teman serta guru sangat minim sekali. Hal tersebut dikarenakan guru kurang dapat menentukan metode pembelajaran yang inovatif serta media pembelajaran yang sesuai dengan materi dan karakteristik siswa. Anak SD kelas 1 merupakan kelas rendah yang rentang dengan 
usia dini. Karakteristik anak pada usia SD memang berbeda-beda anak satu dengan anak lainnya dan karakter anak kelas rendah berbeda dengan karakter kelas tinggi. Anak kelas rendah lebih senang melakukan atau memperagakan sesuatu secara langsung yang ditinjau dari dari teori perkembangan kognitif anak SD yang memasuki tahap operasional kongkrit. Guru hendaknya merancang dan mengembangkan kegiatan pembelajaran yang dapat melibatkan anak dalam proses kegiatan pembelajaran.

Aktivitas yang diperlukan dalam proses tumbuh kembang anak besar di antaranya adalah (Sugiyanto dan Sudjarwo, 1992:127-128): (1)Bermain dalam situasi berlomba atau bertanding dengan pengorganisasian yang sederhana. Misalnya: berlomba dalam beberapa macam gerakan seperti berlari, merayap, melompat, menggiring bola, adu lempar tangkap dan sebagainya. Melakukan pertandingan kecabangan olahraga yang peraturannya disederhanakan, misalnya pertandingan voli mini. Dengan pengarahan dan pengelolaan aktivitas yang baik dari guru, aktivitas ini akan berdampak kepada peningkatan kepercayaan diri anak dan kebanggaan dirinya. (2) Aktivitas beregu atau berkelompok. Anak diberi kesempatan untuk bekerja sama dengan temannya dalam melakukan aktivitas untuk membina kebersamaan di antara mereka.

Dalam pemilihan metode pembelajaran serta media pembelajaran yang dapat mengembangkan aktivitas anak dalam kegiatan pembelajaran serta dapat pula meningkatkan perkembangan sosial melalui kegiatan pembelajaran berlangsung yang sesuai yaitu dengan menerapkan metode role playing berbantu dengan media boneka jari. Pemilihan metode role playing dengan media boneka jari yang sebelumnya sudah disesuaikan berdasarkan materi dan tujuan pembelajaran.

Bermain peran (role playing) adalah penyajian materi pelajaran dengan memperagakan atau mempertunjukkan suatu keadaan atau peristiwa yang dialami orang dengan cara meniru tingkah laku dalam hubungan sosial. Role Playing siswa dapat menghayati peranan apa yang dimainkan, mampu menempatkan diri dalam situasi orang lain yang dikehendaki guru (Wahab, 2000:112). Dengan penerapan metode Role Playing, Siswa memperoleh pengalaman untuk menerima dan membagi tanggung jawab dengan sesamanya dan siswa dapat melatih dirinya untuk melatih 
memahami dan mengingat bahan yang akan didramakan atau diperankan. Sebagai pemain harus memahami dan menghayati isi cerita secara keseluruhan, terutama untuk materi yang harus diperankannya. Dengan demikian daya ingat dan ketrampilan siswa akan terlatih.

Adapun media pembelajaran yang dapat menunjang keberhasilan atau ketercapaian tujuan pembelajaran. Menurut Kurniawan (2004:177) Media Pembelajaran juga dapat diartikan serangkaian usaha yang dilakukan oleh guru dengan tujuan agar terjadi proses belajar pada siswa. Pendapat Imawati (2009: 62)Media boneka jari adalah mascot mungil yang dipasang pada jari untuk dimainkan saat mendongeng (bercerita). Permainan boneka jari akan sangat menyenangkan dan menarik perhatian anak dalam belajar ataupun kegiatan lainnya. Dengan demikian, media boneka jari akan membuat anak lebih bersemangat dalam belajar karena menggunakan prinsip belajar sambil bermain (Madyawati,2017:178).

Dari penjelasan diatas dapat disimpulkan bahwa dengan penerapan metode role playing dengan berbantu media boneka tangan dapat menarik perhatian siswa dalam kegiatan pembelajaran dengan metode tersebut siswa mendapatkan pengalaman yang menyenangkan, serta dapat membangkitkan gairah dalam aktivitas siswa dalam kegiatan pembelajaran sehingga dapat menimbulkan rasa kebersamaan dengan berbantu media boneka tangan dapat mengasah kemampuan sosial anak melalui interaksi dengan teman, berdiskusi dalam menyusun sebuah skenario dengan dialog yang sederhana akan melatih anak dapat membuka komunikasi serta didukung pendapat Tadzkiroatun Musfiroh (2005:22) Media boneka jari dapat mengembangkan imajinasi anak, mempertinggi keaktifan dan menambah suasana gembira.

Dengan demikian, peneliti tertarik melakukan penelitian dengan judul "Penerapan Role Playing Berbantu Media Boneka Jari Dalam Meningkatkan Aktivitas Dan Perkembangan Sosial Siswa Sekolah Dasar"

\section{METODE}

Pada penelitian ini menggunakan jenis penelitian tindakan kelas (PTK). Penelitian tindakan kelas adalah suatu pencermatan terhadap kegiatan belajar berupa sebuah tindakan, yang sengaja dimunculkan dan terjadi dalam sebuah kelas secara bersama (Suharsimi Arikunto, 2006: 3). Penelitian ini ada empat tahap yang terdiri 
dari: perencanaan, pelaksanaan tindakan, observasi dan refleksi. Di setiap siklus melakukan 1 sampai 4 tahap tersebut dan setiap siklus akan melewati ke empat tahap tersebut.

Jumlah siklus akan ditentukan oleh ketercapaian tujuan penelitian. Dan jika tujuan penelitian sudah tercapai pada siklus ke II, maka peneliti cukup melaksanakan penelitian sampai siklus II dan tidak melanjutkan pada berikutnya atau siklus III.

Rencana dalam kegiatan penelitian ini diantaranya yakni mengembangkan perangkat pembelajaran, salah satunya dalam pelaksanaan RPP dalam kegiatan pembelajaran yang telah dikembangkan. Teknik pengumpulan data pada penelitian ini dengan menggunakan wawancara, observasi dan tes. Untuk teknik analisis data dengan menggunakan teknik analisis kuantitatif dan analisis kualitatif. Analisis data kuantitatif untuk mengetahui peningkatan aktivitas siswa dalam kegiatan proses pembelajaran melalui penerapan metode role playing berbantu media boneka jari, dan perkembangan sosial siswa melalui penerapan metode role playing berbantu media boneka jari.

Adapun komponen dalam kriteria aktivitas siswa dalam kegiatan pembelajaran melalui penerapan metode role playing berbantu media boneka jari diantaranya yakni: (1) siswa memperhatikan penjelasan guru dalam memberikan contoh penerapan Role Playing, (2) siswa mampu mengikuti pembelajaran dengan metode Role Playing, (3) siswa mampu menerapkan Role Playing dengan bekerjasama, (4) siswa mampu memainkan boneka jari.

Komponen dalam kriteria perkembangan sosial dalam kegiatan pembelajaran melalui penerapan metode role playing berbantu media boneka jari diantaranya yakni: (1)percaya diri, (2)menghargai perbedaan pendapat, (3)bertanggungjawab dan (4)disiplin

Adapun analisis kualitatif diperoleh melalui lembar observasi yaitu, Pada indikator keberhasilan penelitian ini diantaranya yakni, (1) aktivitas siswa dalam penerapan metode role playing berbantu media boneka jari minimal skor rata-rata $\geq$ 2,5 dengan kriteria baik. (3) perkembangan sosial siswa dengan menerapkan penerapan metode role playing berbantu media boneka secara klasikal yang diperoleh siswa mencapai Presentase $\geq 60 \%$ pada kriteria sangat baik. 


\section{PEMBAHASAN}

Hasil penelitian pada siklus I dalam kegiatan pembelajaran dengan menggunakan metode Role Playing berbantu Media Boneka Jari pada pembelajaran Subtema Aku Merawat Tubuhku yang dikembangkan dalam RPP. Adapun hasil aktivitas siswa dalam kegiatan pembelajaran dapat dilihat pada gambar grafik dibawah ini:

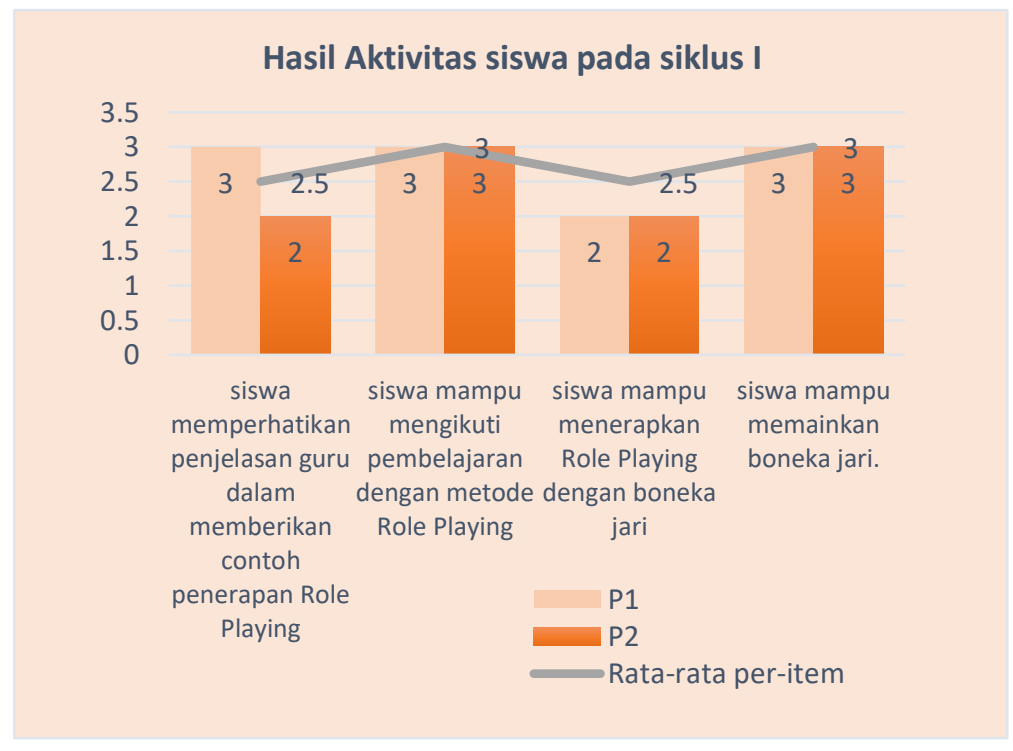

Grafik. 1 Hasil Aktivitas siswa pada siklus I

Dari hasil yang dilakukan dari observasi dari observer pengamat 1 dan pengamat 2 di atas, seperti pada gambar grafik1 atau siklus I (satu) menunjukkan bahwa : (1) siswa memperhatikan penjelasan guru dalam memberikan contoh penerapan Role Playing dengan nilai rata-rata 2,5, masih perlu diitngkatkan lagi dengan memberikan bimbingan kepada siswa dalam penerapan role playing dengan berbantu media boneka jari, (2) siswa mampu mengikuti pembelajaran dengan metode Role Playing dengan nilai rata-rata 3, masih perlu ditingkatkan lagi karena hanya sebagian yang mampu mengikuti pembelajaran dengan metode role playing dengan boneka jari, (3) siswa mampu menerapkan Role Playing dengan boneka jari dengan nilai rata-rata 2,5,siswa masih kurang memahami arti bekerjasama dan peneliti akan memberikan penjelasan kembali pentingnya bekerjasama (4) siswa mampu memainkan boneka jari dengan nilai rata-rata 3, masih perlu ditingkatkan lagi karena terlihat siswa masih ragu-ragu dalam menggunakan boneka jari. 
Terlihat pada gambar grafik1. Hasil nilai rata-rata dari pengamat 1 yaitu dari guru kelas memperoleh rata-rata 2.75 dengan presentase $55 \%$ dan pengamat 2 dari teman sejawat memperoleh rata-rata 2.5 dengan jumlah presentase $50 \%$. Dari hasil rata-rata 2.75 dan jumlah presentase sebesar 55\% dapat disimpulkan jika aktivitas siswa dalam kegiatan pembelajaran metode role playing berbantu boneka jari belum mencapai presentase indikator keberhasilan pada aktivitas siswa yaitu $80 \%$.

Adapun hasil dari perbaikan dari Aktivitas siswa dalam penerapan metode role playing berbantu boneka jari yang disajikan pada gambar grafik2. pada siklus II perbaikan dari siklus I:

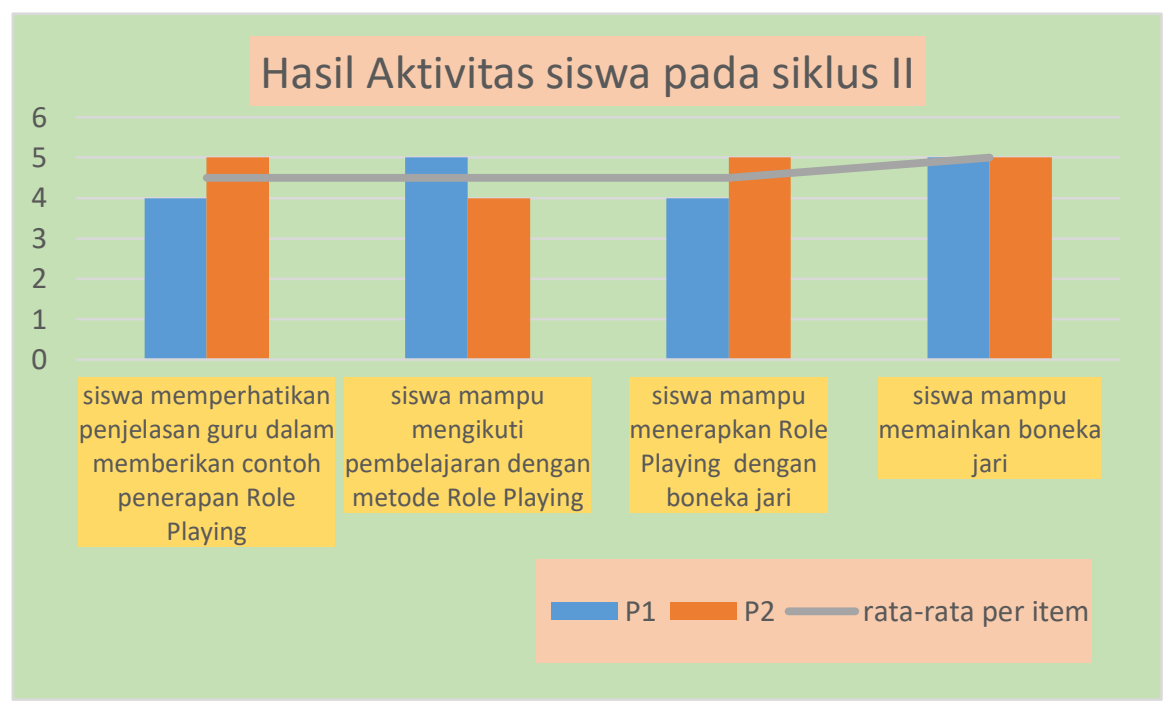

Grafik. 2 Hasil Aktivitas siswa pada siklus II

Dari hasil yang dilakukan dari observasi dari observer pengamat 1 dan pengamat 2 pada siklus II, seperti pada gambar grafik2. menunjukkan bahwa : (1) siswa memperhatikan penjelasan guru dalam memberikan contoh penerapan Role Playing mengalamai peningkatan sebesar 2 dari rata-rata 2,5 menjadi sebesar 4,5 (2) siswa mampu mengikuti pembelajaran dengan metode Role Playing mengalami peningkatan sebesar 1,5 dari rata-rata 3 menjadi sebesar 4,5,(3) siswa mampu menerapkan Role Playing dengan boneka jari meningkat sebesar 2 dari rata-rata 2,5 menjadi sebesar 4,5 (4) siswa mampu memainkan boneka jari mengalami peningkatan sebesar 2 dari ratarata 3 menjadi sebesar 5 .

Terlihat pada gambar grafik2. Hasil nilai rata-rata dari pengamat 1 yaitu dari guru kelas meningkat sebesar 1,75 dari rata-rata 2,75 menjadi sebesar 4,5 dengan 
presentase $90 \%$ dan pengamat 2 dari teman sejawat memperoleh rata-rata 4,75 meningkat sebesar 2,25 dengan presentase sebesar 95\%. Dari hasil rata-rata sebesar 4,62 dan jumlah presentase sebesar 92,5\% dapat disimpulkan jika aktivitas siswa dalam kegiatan pembelajaran metode role playing berbantu boneka jari sudah mencapai presentase indikator keberhasilan pada aktivitas siswa yaitu $80 \%$.

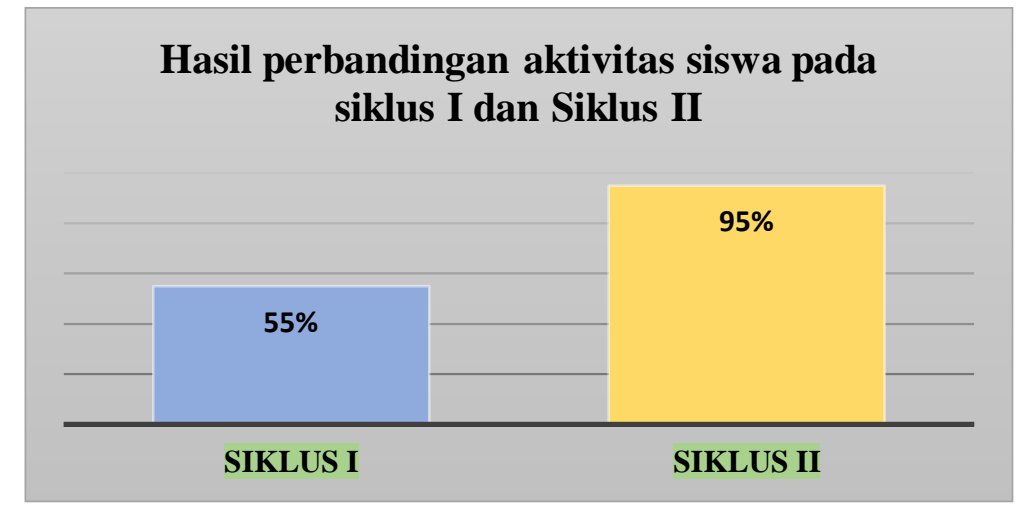

Grafik. 3 Hasil perbanduingan aktivitas siswa pada siklus I dan II

Berdasarkan grafik diatas terlihat bahwa aktivitas siswa dalam mengikuti penerapan pembelajaran dengan metode role playing berbantu media boneka jari pada siklus I memperoleh presentase sebesar 55\% dengan hasil tersebut siklus I belum mencapai ketuntasan presentase. Setelah ada perbaikan pada tahap siklus II peneliti meningkatkan kriteria aktivitas siswa yang diperoleh skor kurang pada siklus I meningkat sebesar $40 \%$ dengan presentase sebesar 95\% pada siklus II. Dengan demikian, hasil aktivitas telah mencapai keberhasilan dalam mengikuti penerapan pembelajaran dengan metode role playing berbantu media boneka jari.

Aktivitas pembelajaran dengan kegiatan yang dilakukan dalam proses pembelajaran berlangsung harus ada interaksi antara guru dan siswa dalam mencapai tujuan pembelajaran. Oemar Hamalik (2009: 179) menyatakan bahwa aktivitas belajar merupakan kegiatan yang dilakukan oleh siswa dalam kegiatan pembelajaran. Aktivitas belajar yang efektif akan terwujud apabila siswa terlibat aktif dalam kegiatan pembelajaran.Menurut Martinis Yamin (2007: 82) mendefinisikan belajar aktif sebagai usaha manusia untuk membangun pengetahuan dalam dirinya. Pembelajaran akan menghasilkan suatu perubahan dan peningkatan kemampuan, pengetahuan dan ketrampilan pada diri siswa. Siswa mampu menggali kemampuannya dengan rasa 
ingin tahunya sehingga interaksi yang terjadi akan menjadi pengalaman dan keinginan untuk mengetahui sesuatu yang baru.

Hasil penelitian pada siklus I dalam perkembangan sosial siswa melalui penerapan metode role playing berbantu boneka jari. Adapun hasil perkembangan sosial siswa dalam kegiatan pembelajaran dapat dilihat pada gambar grafik 4. dibawah ini:

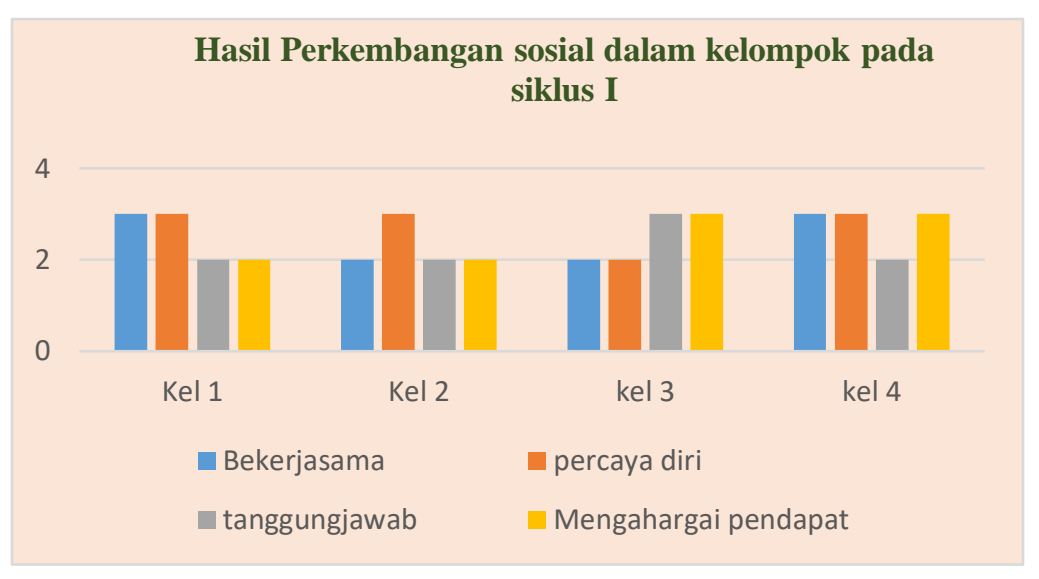

Grafik. 4 Hasil perkembangan social dalam kelompok pada siklus I

Berdasarkan hasil grafik diatas. Dari hasil perkembangan sosial siswa ketika mengikuti kegiatan pembelajaran dengan metode role playing berbantu media boneka jari pada aspek (1)bekerjasama dengan nilai rata-rata 2,5 dan presentase sebesar 50\%, (2)bertanggungjawab dengan nilai rata-rata sebesar 2,25 dan presentase sebesar 40\%, (3)percaya diri dengan nilai rata-rata 2,75 dan presentase sebesar 55\% (4)menghargai pendapat dengan nilai rata-rata 2,5 dan presentase sebesar $50 \%$.

Dari hasil diatas menujukkan bahwa dari aspek (1) bekerjasama, siswa masih kurang dan terlihat dalam kegiatan pembelajaran masih terlihat individu, (2)bertanggungjawab, siswa masih belum memahami bagaimana bertanggungjawab ketika mengikuti kegiatan pembelajaran misalnya ketika menerapkan role playing berbantu boneka jari beberapa siswa jika diingatkan oleh teman dan guru (peneliti) mereka masih suka ngambek dan tidak mau diingatkan jika hal yang dilakukan salah, (3)percaya diri, masih banyak siswa yang kurang percaya diri ketika memainkan skenario dengan boneka jari terlihat masih ragu dan malu serta takut salah, (4)menghargai pendapat, masih banyak siswa yang kurang menghargai pendapat teman terlihat sering marah atau membentak temannya jika ada yang memberi saran atau pendapat. 
Berdasarkan hasil, perkembangan sosial melalui penerapan metode role palying berbantu media boneka jari memperoleh rata-rata 2,5 dengan presentase sebesar 50\%. Hal ini berarti belum mencapai ketuntasan pada indikator keberhasilan yaitu $80 \%$. Dan perlu perbaikan pada siklus berikutnya yaitu siklus ke II. Hasil perbaikan pada siklus II dapat dilihat pada gambar grafikdibawah ini:

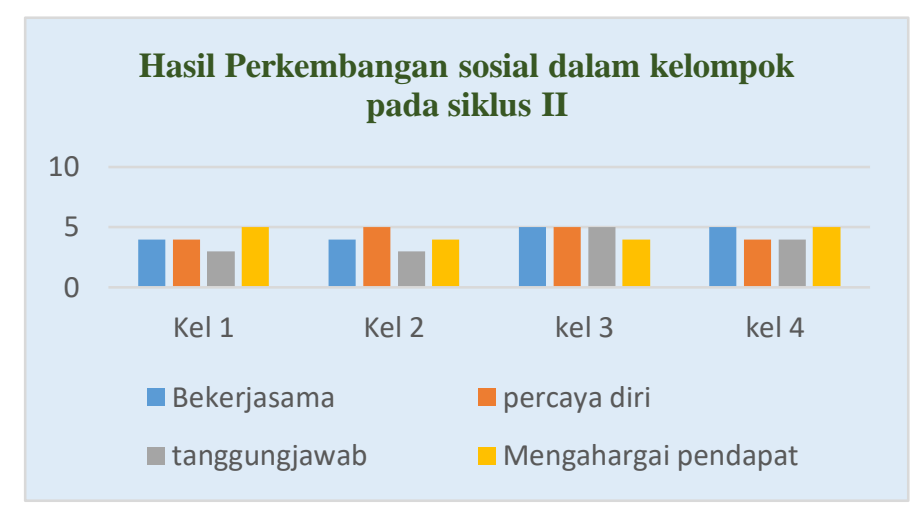

Grafik. 5 Hasil perkembangan social dalam kelompok pada siklus II

Berdasarkan hasil dari gambar grafik5. Dari hasil perkembangan sosial siswa ketika mengikuti kegiatan pembelajaran dengan metode role playing berbantu media boneka jari pada aspek (1)bekerjasama dengan nilai rata-rata 4,5 dan presentase sebesar 90\%, (2)bertanggungjawab dengan nilai rata-rata 4,5 sebesar dan presentase sebesar 90\%, (3)percaya diri dengan nilai rata-rata 3,75 dan presentase sebesar 75\%, (4)menghargai pendapat dengan nilai rata-rata 4,5 dan presentase sebesar $90 \%$.

Dari hasil diatas menujukkan bahwa dari aspek (1) bekerjasama, dengan bimbingan guru (peneliti) dengan menjelaskan pentingnya bekerjasama dalam kelompok, rata-rata siswa sudah dapat bekerjasama dengan kelompok yang terlihat ketika mengikuti kegiatan pembelajaran saling membantu temannya ketika ragu menggerakkan boneka jarinya, (2)bertanggungjawab, lewat bimbingan guru (peneliti) memberikan penjelasan tentang bertanggung jawab serta contohnya siswa dapat beratnggung jawab dalam kelompok, jika ada yang mengingatkan sudah tidak marah dan saling belajar dengan teman lainnya, (3)percaya diri, dengan motivasi dari guru (peneliti) dan teman lainnya bahwa kita semua yang ada didalam kelas sedang bermain dan belajar, dari situlah siswa sudah tidak malu lagi dalam memainkan boneka jari dengan teks skenario, (4)menghargai pendapat, dengan arahan dan bimbingan guru (peneliti) tentang pentingnya menghargai pendapat teman lain dalam bermain dan 
belajar dari situlah siswa mengikuti kegiatan sudah tidak lagi marah dan menangis jika ada yang berpendapat dari teman lainnya.

Perkembangan sosial anak, dimana ketika anak usia dini berinteraksi langusng dengan teman sebayanya, dengan orang yang lebih dewasa serta masyarakat yang ada di lingkungan sekitarnya. Menurut Hurlock (1995:250), Perkembangan Sosial berarti " Perolehan kemampuan berperilaku yang sesuai dengan tuntutan sosial. Menjadi orang yang mampu bermasyarakat (sozialized) memerlukan tiga proses. Diantaranya adalah belajar berperilaku yang dapat diterima secara sosial, memainkan peran sosial yang dapat diterima, dan perkembangan sifat sosial. Perkembangan sosial anak itu sendiri akan mengajarkan anak menjadi anak yang bisa menghargai pendapat orang lain, bekerjasama dan saling menerima. Menurut Ahmad Susanto, (2012:40) perkembangan sosial merupakan " Pencapaian kematangan dalam hubungan sosial. Dapat juga diartikan sebagai proses belajar untuk menyesuaikan diri terhadap normanorma kelompok, moral, dan tradisi, meleburkan diri menjadi satu kesatuan dan saling berkomunikasi dan bekerja sama.

Berdasarkan hasil, perkembangan sosial melalui penerapan metode role palying berbantu media boneka jari memperoleh rata-rata 4,31 dengan presentase sebesar 86,25\%. Hal ini berarti sudah mencapai ketuntasan pada indikator keberhasilan yaitu $80 \%$.

Pada hasil siklus II yang sudah mencapai ketuntasan indikator keberhasilan, dapat disimpulkan melalui penerapan metode role playing berbantu media boneka jari dapat meningkatkan perkembangan siswa.

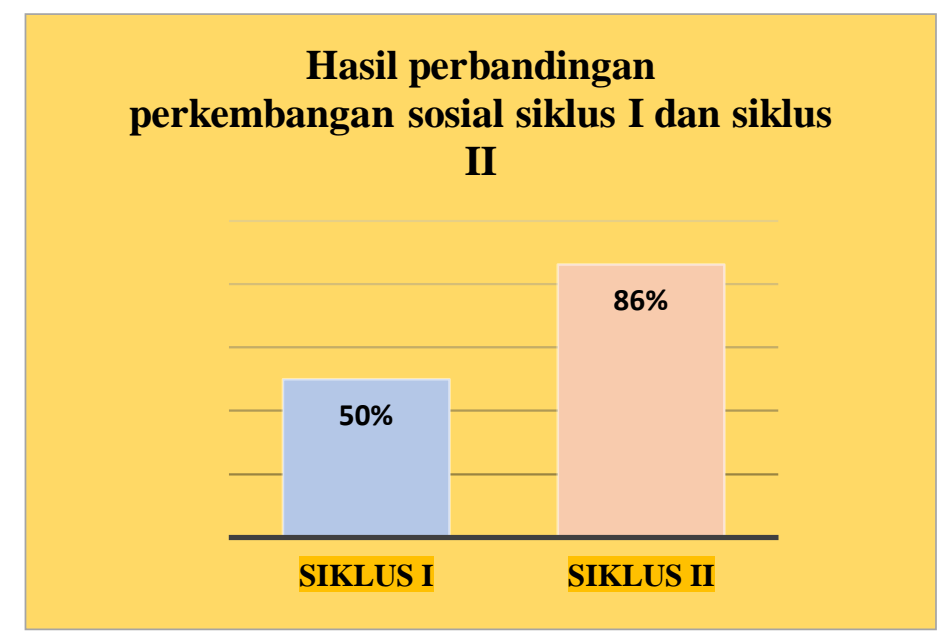

Grafik. 6 Hasil perbandingan perkembangan sosial siswa dalam setiap siklus 
Berdasarkan Grafik 6. terlihat bahwa perkembangan sosial siswa dalam mengikuti penerapan pembelajaran dengan metode role playing berbantu media boneka jari pada siklus I memperoleh presentase sebesar 50\% dengan hasil tersebut siklus I belum mencapai ketuntasan presentase. Setelah ada perbaikan pada tahap siklus II peneliti meningkatkan kriteria perkembangan sosial meningkat sebesar $36 \%$ dengan presentase sebesar $86 \%$ pada siklus II. Dengan demikian, hasil perkembangan sosial telah mencapai keberhasilan dalam mengikuti penerapan pembelajaran dengan metode role playing berbantu media boneka jari.

\section{SIMPULAN}

Penerapan Metode Role Playing Berbantu Media Jari Tangan pada siswa kelas 1 SDN 1 Krian. Pada hasil penelitian dapat disimpulkan dalam penelitian ini dilaksanakan sampai siklus II. Hasil dari aktivitas siswa dalam mengikuti kegiatan pembelajaran melalui penerapan metode role playing berbantu media boneka jari dari siklus I memperoleh nilai rata-rata sebesar 2.75 dan jumlah presentase sebesar 55\% meningkat pada siklus II dengan nilai rata-rata 4,62 dan jumlah presentase sebesar 92,5\%. Adapun hasil dari perkembangan sosial siswa dalam mengikuti kegiatan pembelajaran melalui penerapan metode role playing berbantu media boneka jari memperoleh rata-rata 2,5 dengan presentase sebesar 50\% meningkat pada siklus II dengan nilai rata-rata sebesar rata-rata 4,31 dengan presentase sebesar 86,25\%. Dengan adanya hasil tersebut dapat dinyatakan dengan adanya penerapan metode yang inovatif yaitu dengan menggunakan metode Role Playing dengan berbantu Media Jari Tangan dapat meningkatkan Aktivitas dan Perkembangan sosial siswa dalam pembelajaran.

\section{UCAPAN TERIMA KASIH}

Penulis mengucapkan terima kasih kepada STAI AL- AZHAR Menganti Gresik yang telah memfasilitasi penelitian ini dan tim penelitian hingga selesai serta pengelola jurnal ABATA yang telah menerbitkan artikel ini. 


\section{REFERENSI}

Ahmad Susanto. 2012. Perkembangan Anak Usia Dini :Pengantar dalam Berbagai Aspeknya. Jakarta: Kencana Prenada Media Group

Arikunto. Suharsimi. 2006. Prosedur Penelitian Suatu Pendekatan Praktik. Jakarta: Rineka Cipta.

Deni Kurniawan. 2014. Pembelajaran Terpadu Tematik. Bandung: Alfabet

Elizabeth B. Hurlock. 1995. Perkembangan Anak Jilid 1. Jakarta: Penerbit Erlangga

Hamalik, Oemar. 2009. Kurikulum dan Pembelajaran. Jakarta. Bumi Aksara

Madyawati, Lilis. 2017. Strategi Pengembangan Bahasa Pada Anak. Jakarta: Prenada Media Group

Martinis Yamin, 2007. Kiat Membelajarkan Siswa. Jakarta. Gaung Persada Press dan Center for Learning Innovation (CLI).

Imawati, Emi Risna. 2009. Kreasi Tokoh Fantasi dari Kain Felt. Jakarta: Gramedia

Musfiroh, Tadkiroatun. 2005. Bermain Sambil Belajar dan Mengasah Kecerdasan. Jakarta. Depdiknas

Sugiyanto dan Sudjarwo. 1992. Materi Pokok Perkembangan dan Belajar Gerak. Jakarta: depdikbud. Proyek Peningkatan Mutu Guru SD Setara D-II

Wahab, A. 1998. Metodologi Pengajaran IPS. Jakarta : Karunia

Arikunto, Suharsimi, dkk. 2011. Penelitian Tindakan Kelas. Jakarta: PT Bumi Aksara.

Wardhani, I.G.A.K \& Wirhadit. 2009. Penelitian Tindakan Kelas. Jakarta: Universitas Terbuka

Fadillah, Muhammad dkk. 2014. Pendidikan karakter Anak Usia Dini. Jogjakarta: Arruzz Media

Mulyasa. 2011. Manajemen Pendidikan Karakter. Jakarta: Bumi Aksara.

Conny R. Semiawan. 2008. Belajar dan Pembelajaran Prasekolah Dan Sekolah Dasar. Jakarta: Indeks

Syarbini, Amirulloh. 2013. Model Pendidikan Karakter dalam Keluarga. Bandung: Eka Media Komputindo 